Thorax (1976), 31, 118.

\title{
Resection of a leiomyoma of the descending thoracic aorta
}

\author{
G. G ULA ${ }^{1}, A$. CA N C R I I, a nd L.PROVENZALE \\ University Department of Cardiovascular Surgery, Policlinico Hospital, 00161 Rome, Italy
}

\begin{abstract}
Gula, G., Cancrini, A., and Provenzale, L. (1976). Thorax, 31, 118-120. Resection of a leiomyoma of the descending thoracic aorta. A primary aortic neoplasm in a 4-year-old asymptomatic boy is described. At operation the tumour was found to originate from the descending thoracic aorta. Histologically it proved to be a leiomyoma. The operative findings and pathological features are briefly discussed.
\end{abstract}

Primary aortic neoplasms are rare. To our knowledge only 17 cases have been described in the literature since Brodowski's initial report in 1873 (Detrie, 1960; Stevenson et al., 1971; Winkelmann, van Heerden and Bernatz, 1971; Silverman and Waxlen, 1972; Kimbrell and Kaasa, 1973).

This report describes one additional case of aortic leiomyoma that we have recently encountered.

\section{CASE HISTORY}

A 4-year-old boy was admitted to hospital in 1973 because of an asymptomatic mass in the left hilum, discovered on chest radiography.

On admission physical examination and electrocardiogram were entirely normal. The chest radiographs (Fig. 1a, b) revealed a well-circumscribed opacity in the left hilum and normal vascularity in the lung fields. Bronchoscopy was not contributory. At catheterization and angiography the heart and large vessels appeared completely normal.

OPERATIVE FINDINGS Operation was performed through a standard left posterolateral thoracotomy. The lesion, arising from the anterior surface of the aorta at the level of the fifth to sixth intercostal space without pleural adhesions, was excised, and the vessel was clamped above and below the mass, together with a small piece of the aortic wall almost destroyed at that level by the tumour (clamping time 13 minutes). Aortic continuity was restored with the aid of a Dacron patch and continuous suture. 1Present address: Cardiothoracic Unit, Harefield Hospital, Harefield,
Middlesex, England
The postoperative course was uneventful and产 the patient was discharged from hospital after $\vec{\theta}$ two weeks.

PATHOLOGICAL FEATURES Grossly the tumour was oval with a smooth, regular, external surface, measuring $7 \times 4 \mathrm{~cm}$ and weighing 60 grams. Cut $\stackrel{2}{\%}$ section of the specimen showed the typical micro- $\stackrel{\odot}{\circ}$ scopic appearance of a benign leiomyoma without $\vec{\overrightarrow{ }}$ anaplastic changes (Fig. 2). The aortic wall was 3 almost completely destroyed by the tumour and only a few elastic fibres could be demonstrated.

Primary tumours of the aorta are rare. The youngest patient affected by this lesion, as re-응 ported in the literature, was $3 \frac{1}{2}$ months old, the oldest 65 years. Three were male and 14 femaleo patients. Clinical symptoms depend upon the tumour's location. In some cases the intraluminalo development of the lesion may simulate the symp- $₹$ toms of coarctation of the aorta. Severe acceler-o ating hypertension was documented in four cases $\square$ reported by Stevenson et al. (1971).

Kattus et al. (1960) made the first successful antemortem diagnosis, followed by Silverman and Waxlen (1972), who described the typical angio- $N$ graphic findings in a case of intraluminal myxoma N of the aorta.

In most cases the primary tumour remains localized to the intimal layer, although extension through all layers of the aorta has been described? (Aussermann, 1911; Nencki, 1946; Zeilhofer, to Holzner, and Krepler, 1963).

In our patient the lesion, because of its develop- $\mathbb{D}$ ment towards the external layers of the aortico wall, was asymptomatic until it was discoveredo in a routine chest film. For the same reason 
(a)
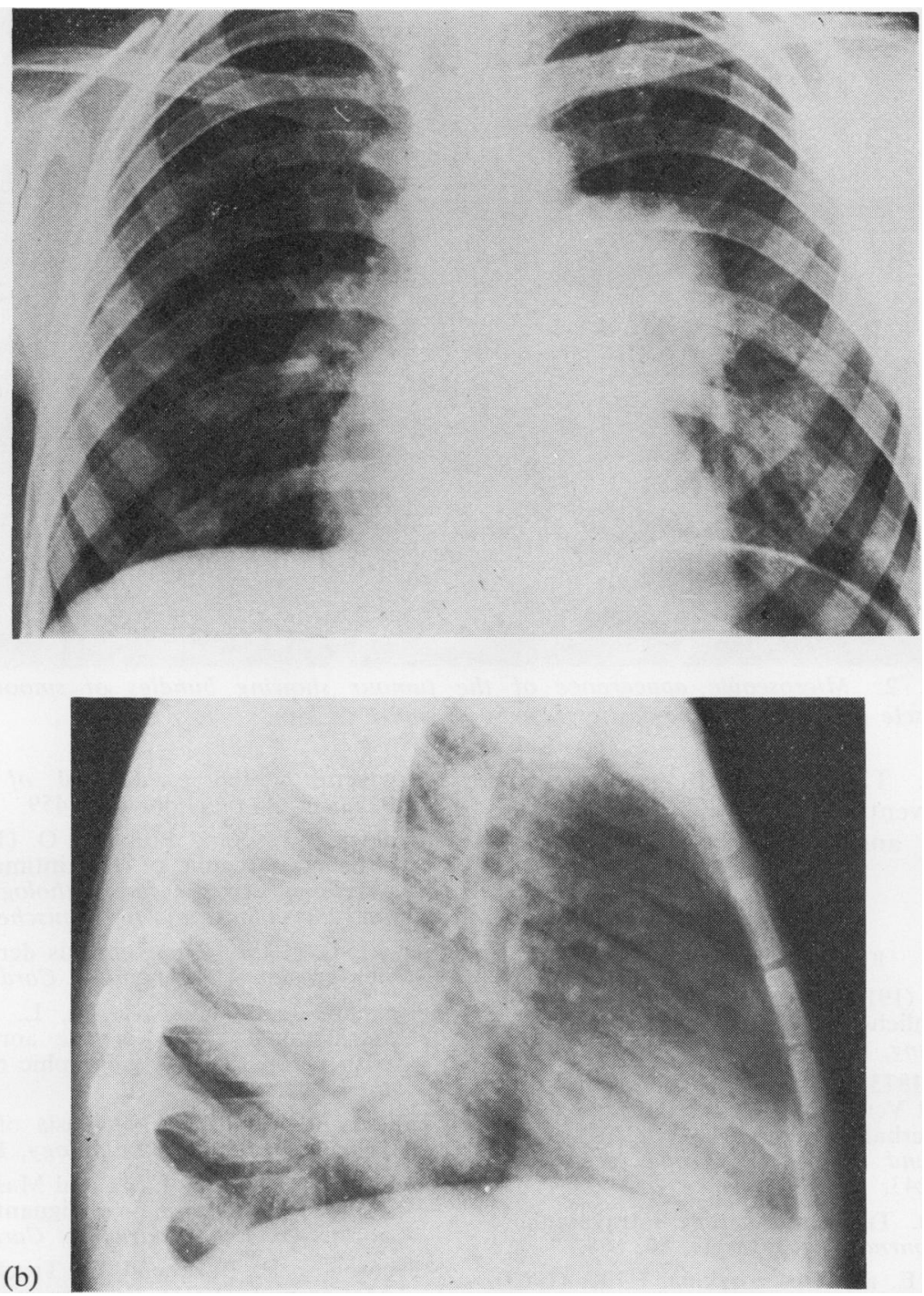

FIG. 1. Postero-anterior (a) and lateral (b) chest radiographs showing a homogenous parahilar mass on the left side located near the spine.

catheterization and angiography were also unhelpful in reaching the diagnosis preoperatively.

The microscopic diagnoses offered are numerous, for example, myxoma, fibromyxoma, fibromyxosarcoma, angiosarcoma, and endothelioma (Karhoff, 1952; Kovaleva and Press, 1959; Kaigorodova and Berezovskaia, 1963; Sladden, 1964; Smeloff, Reece, and Master, 1965).

Primary tumours of the aorta have a definite potential to embolize and metastasize widely. Emboli may occur in the spleen, liver, kidney, pan- creas, pelvic bones, pleura, skin, and spine (Kimbrell and Kaasa, 1973).

From the surgical point of view excision seems, in some instances, feasible although in many cases it has not been accomplished. To our knowledge, only one case has been resected with good longterm results (Kattus et al., 1960).

In our patient the diagnosis was made at the time of operation, followed by excision of the lesion. The microscopic appearance was of a typical benign leiomyoma with absence of ana- 


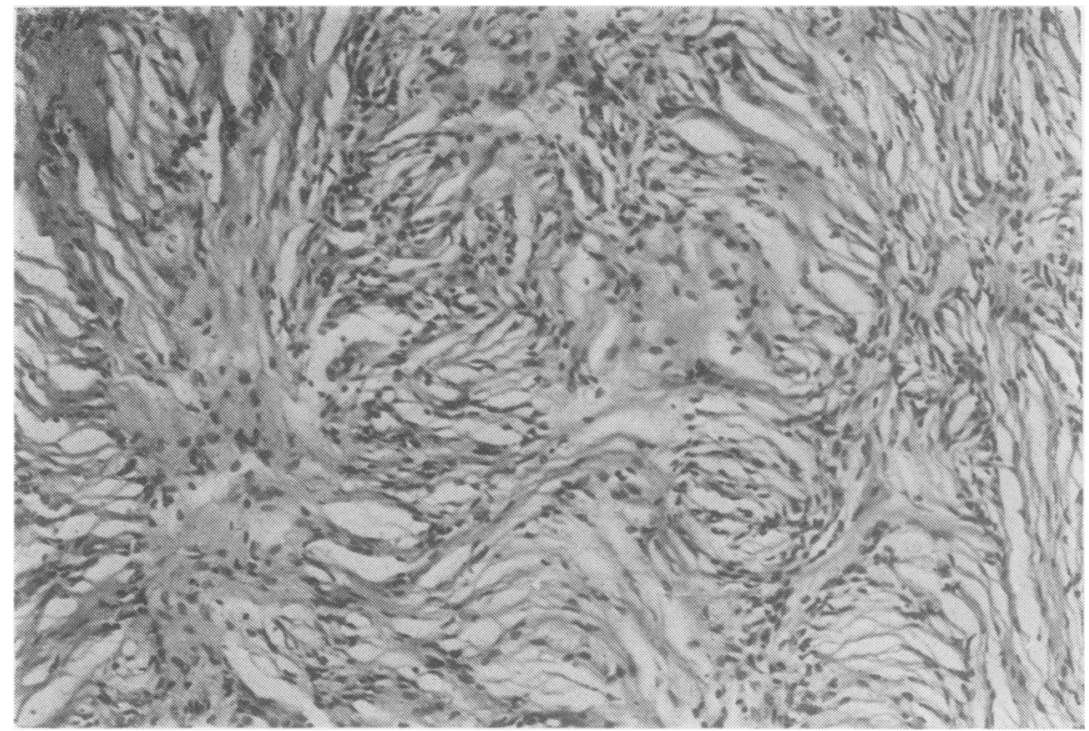

FIG. 2. Microscopic appearance of the tumour showing bundles of smooth muscle cells without anaplastic changes $(H$ and $E \times 346)$.

plastic changes. The immediate postoperative course was uneventful, and two years later the patient is alive and well without evidence of recurrence.

\section{REFERENCES}

Aussermann, H. (1911). Primäres Aortengeschwulst mit eigentümlichen Riesenzellen. Zeitschrift für Krebsforschung, 11, 294.

Brodowski, W. (1873). Primäres Sarkom der Aorta thoracica mit Verbreitung des Neugebildes in der Unterenkörperhalfte. Jahresbericht über die Leistungen und Fortschritte in der gesammten Medicin, 8, 243.

Detrie, P. (1960). Tumeur primitive intravasculaire de l'aorte. Journal de Chirurgie, 80, 666.

Kaigorodova, R. E. and Berezovskaia, E. K. (1963). Endothelioma of the thoracic aorta. Grudnaya Khirurgiya, 5, 88.

Karhoff, B. (1952). Primär Tumor der Aorta. Zentralblatt für allgemeine Pathologie und pathologische A natomie (Abstract), 89, 46.

Kattus, A. A., Longmire, W. P., Cannon, J. A., Webb, R., and Johnston, C. (1960). Primary intraluminal tumor of the aorta producing malignant hypertension. New England Journal of Medicine, 262, 694.

Kimbrell, O. C. and Kaasa, L. J. (1973). Primary intraluminal aortic myxoma involvement of several vertebrae. Journal of the American Medical Association, 226, 459.

Kovaleva, A. N. and Press, B. O. (1959). A case of primary sarcoma of the intima of the aorta. $\bigcirc$ Virchows Archiv für pathologische Anatomie $\overrightarrow{\vec{B}}$ und Physiologie und für klinische Medizin, 21, 62.

Nencki, L. (1946). Zur Kenntnis der Primärtumoren der grossen Gefasstamme. Cardiologia, 10, 1.

Silverman, J. F. and Waxlen, L. (1972). Primary intraluminal tumor of the aorta: case report with preoperative angiographic diagnosis. Radio$\log y, 102,581$.

Sladden, R. A. (1964). Neoplasia of aortica intima. Journal of Clinical Pathology, 17, 602.

Smeloff, E. A., Reece, J. M., and Master, J. H. (1965). ठิ Primary intraluminal malignant tumor of the aorta. American Journal of Cardiology, 15, 107. 웅

Stevenson, J. E., Burkhead, H., Trueheart, R. E., and McLaren, J. (1971). Primary malignant tumor of the aorta. American Journal of Medicine, 51, 553.

Winkelmann, R. K., van Heerden, J. A., and Bernatz, $\widetilde{\sigma}$ P. E. (1971). Malignant vascular endothelial tumor with distal embolization. A new entity. O American Journal of Medicine, 51, 692.

Zeilhofer, J., Holzner, J. H., and Krepler, P. (1963). O Primäres Fibromyxosarkom der Aorta. Krebsartz, 18, 259.

Requests for reprints to: Dr. G. Gula, Cardiothoracic $\stackrel{-}{-}$ Unit, Harefield Hospital, Harefield, Middlesex. 